\title{
Competing with computers: an integrated approach to identifying areas of competitive advantage
}

\author{
R.T. Watson \\ Department of Information Systems, School of Business, Western Australian College, Perth, Western Australia \\ L.F. Pitt ${ }^{\star}$ \\ School of Management, Curtin University of Technology, Kent St., Bentley, WA6102, Australia
}

\begin{abstract}
The potential for information systems technology (IST) to afford competitive advantages to organizations which exploit it effectively has been well documented. However, there has not been a great deal of work in the area of how managers can identify opportunities for the strategic use of IST. Three broad approaches have been outlined for the identification of these opportunities, namely brainstorming, case studies, and conceptual models. The authors present an overview of these approaches and then suggest their integration in a process model which should lead to synergy in strategy teams charged with the identification of strategic uses of IST.
\end{abstract}

\begin{abstract}
Die potensiële gebruik van inligtingstelseltegnologie (IST) om mededingende voordeel te verkry het alreeds wye aandag in die literatuur ontvang. Hoe bestuurders geleenthede vir die strategiese benutting van IST kan identifiseer is egter 'n gebied waarin daar nog nie veel werk gedoen is nie. Drie breë benaderings word uiteengesit vir die identifisering van die geleenthede, naamlik denkskrums, gevalle studies en konseptuele modelle. Die outeurs bied 'n oorsig van die benaderings, en stel dan hul integrasie in 'n prosesmodel voor wat 'n sinergistiese effek kan hê in strategiese spanne wat as opdrag het die identifisering van strategiese gebruike van IST.
\end{abstract}

* To whom correspondence should be addressed

\section{Introduction}

A recent study has rated strategic planning for information systems technology (IST) as the number one issue by MIS executives (Brancheau \& Wetherbe, 1987), and most senior managers today are aware that IST can be used to create a competitive advantage. The acknowledgement of this advantage is an obvious first step in the development of systems that will exploit the technology's potential.. The second step is a more difficult one because it requires harnessing the creative energy of senior managers. This calls for a synergistic effort by executives in functional areas, such as marketing and production - people who understand the business - and, IS -specialists, the people who understand the technology. It is apparent that the identification of these strategic alternatives is an operose task. Yet IST offers considerable opportunities to expand the range of alternative strategies that an organization may pursue in order to gain superior returns. In this short paper the authors present a brief review of a number of approaches that may be used to discover competitive systems and introduce a new method designed to focus on opportunities for their exploitation.

\section{Identifying competitive information systems: some approaches}

An organization can typically utilize one of three broad approaches to identify competitive information systems, namely idea generation methods, case studies, and conceptual models. Whereas efforts in the past have tended to use these methods in isolation, a contention of this paper is that they should be synergistically combined to extract their maximum potential.

\section{Brainstorming}

Brainstorming, popularized by Osborn (1941), is a commonly known technique that can be used by groups to generate better ideas. Interacting groups, which concentrate upon the generation of ideas and avoid criticism of any proffered thoughts, will produce more alternatives than an equal number of individuals working alone. Synectics (Gordon, 1961), Nominal Group Technique [NGT] (Van de Ven \& Delbeqc, 1971), and Snow-Card (Duke \& Greenblatt, 1979) are some of the other approaches to group idea production which have been spawned by Osborn's work. A review by Jablin \& Siebold (1978) concludes that the most effective method of group problem solving is achieved by a four stage process:

group orientation to the problem;

individual brainstorming;

collective pooling of ideas; and

group evaluation and selection of ideas.

These processes have been incorporated into Group Decision Support Systems [GDSS] (DeSanctis \& Gallupe, 1987) that can assist, amongst other things, in the generation of alternatives by problem solving groups. An expertmental GDSS - SAMM, developed at the University of Minnesota - for example, supports NGT and Snow-Card (DeSanctis, Sambamurthy \& Watson, 1987). Group problem solving techniques that enhance group idea development could be used by senior executives wishing to identify strategic information systems. With the development of GDSS technology, which automates aspects of the idea development process, a group can achieve higher levels of idea production (Applegate, 1986). 


\section{Case studies}

Case studies of organizations that have successfully implemented competitive information systems provide learning models for other enterprises. Several authors have made extensive use of case studies in describing strategic information systems (Ives \& Learmonth, 1984; Beath \& Ives, 1986; Ives \& Vitale, 1988). American Hospitals Supplies (AHS) is the success story - or case study - that alerted both academics and practitioners to the active role that IST can play in the execution of corporate strategy (Information Week, 1986). US drug wholesaler, Foremost-McKesson, ensured its survival by being more cost effective than manufacturer's sales branches, using IST. Seventy-two of its warehouses are automated; it has direct computer links with 32 manufacturers; it has established a computerized accounts-receivable system for pharmacists; and, has provided drug stores with terminals for inventory reordering (Business Week, 1981). International furniture giant, the Swedish IKEA company, has reached the top using IST despite the fact that its distribution channels stretch from Stockholm to Sydney (Watson \& Pitt, 1989). A suppliers data base manages over 1500 individual suppliers. Computers are utilized to ensure that every IKEA consignment is optimized in terms of mass and volume. Sophisticated algorithms are used to calculate optimum stacking patterns for packages on pallets.

In South Africa success stories to match anything the international sphere has to offer are beginning to make themselves known. A major record distributor, for example, has equipped its merchandisers with hand-held computers and bar code scanners for taking stock in discount stores, supermarkets, and specialist record outlets. When one realises that a recording artist like the late Elvis Presley made over 100 long players, most of which still sell reasonably well, the victory over the onerous task of stock taking provided by IST becomes apparent ${ }^{1}$. In the area of pharmaceutical marketing, a leading manufacturer has issued its representatives with battery-powered lap-top computers. These are used to store technical information on all of the company's considerable range of complex products, as well as profiles of each of the few hundred prescribing doctors the saleperson calls on each month. The computer provides an excellent diary and sales day planner, as well as alleviating the tiresome chore of compiling the weekly call report ${ }^{2}$. One of South Africa's leading hardware wholesalers now equips its sales representatives with portable facsimile machines so that orders can be faxed through from customers' telephones, ensuring same or next day delivery, guaranteeing detail, and negating the need for an orders clerk completing further written orders at a head office warehouse. Meaningful competitive advantage over competitors is of course ensured ${ }^{3}$.

Case studies play a cardinal role in the transmission of new ideas. The many late adopters of an innovation assess the experiences of the fewer earlier adopters before making a decision (Rogers, 1983), and vicarious modelling, or discovering from observing the behaviour of others, is used by both individuals and organizations to learn about new ideas (Bandura, 1977). Case studies that describe the strategic use of IST, bring the notion of competing with computers into popular currency and give insights that permit the reader to visualize how a similar system may assist his own organization. Organizations searching for competitive information systems can use case studies as a fruitful starting point for identifying systems that fit their competitive environment.

\section{Conceptual models}

Structure can be introduced to the problem-solving process by the use of conceptual models. Executives can use them to focus on the key areas of concern. The quality of group decision making can be improved by structure (Delbecq \& Van de Ven, 1971; Hirokawa \& Pace, 1983), and a conceptual model is a form of structure that supports systematic exploration for alternatives. Furthermore a model can focus attention on one part of the problem space. The Ives \& Learmonth (1984) customer resource life cycle model, for example, directs attention to the relationship between the organization and the customer for 13 different types of transactions. A number of models, generally drawn from industrial organization and marketing, have been used to classify observed strategic information systems, and these taxonomies can be used to structure the search for new opportunities. Some of the models are:

the competitive forces model (Parsons, 1983);

the value chain (Porter \& Miller, 1985);

the customer resource life cycle model (Ives \& Learmonth, 1984);

the product pricing model (Beath \& Ives, 1986); and the trigger-input-process-output model for maintenance (Ives \& Vitale, 1988).

These frameworks provide a structure within which groups of strategic planners can operate in their efforts to identify opportunities to effectively compete using IST.

\section{Integration of the approaches}

While many organizations may wish to explore the opportunities IST can offer in achieving competitive advantage, managers may have a feeling of not knowing where to start looking. The three methods outlined above can be combined to provide an integrated approach to the identification of opportunities for using IST to gain competitive advantage. This approach is illustrated in Figure 1. A team of managers in an organization can use it to examine the strategic issues of using IST in achieving competitive advantage. A planning session which sought to explore alternatives for the company to exploit, would begin with a general orientation of the team members to the problem at hand. Next, the planning team would choose a conceptual model of the activities involved in the area concerned. Although the organization could choose to use one of 


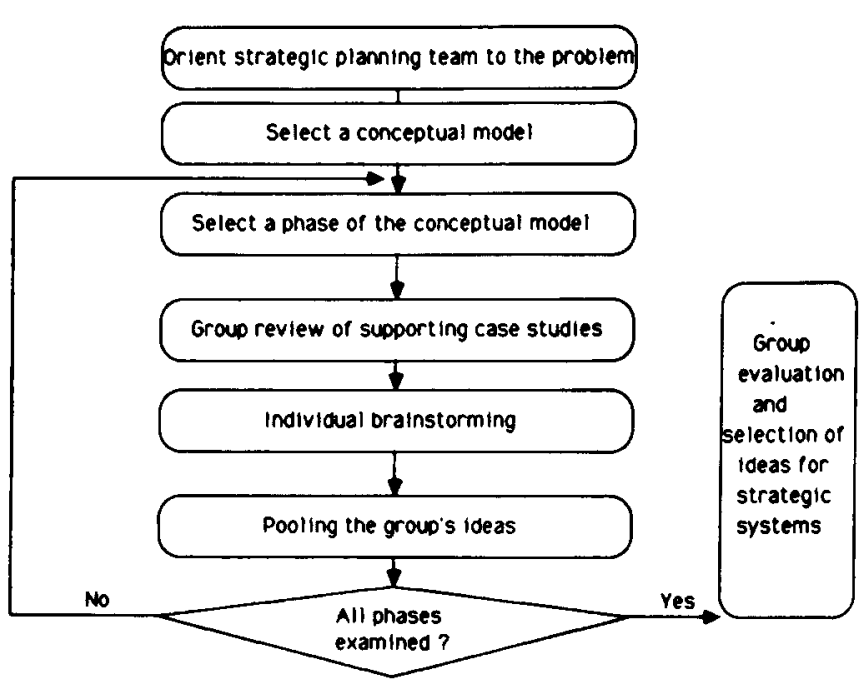

Figure 1 Process model for the identification of strategic uses of IST

the conceptual models already referred to, it could quite conceivably have a model of its own. The third step in the process is for a phase of the conceptual model to be selected and focused on. The group can then review supporting case studies from within the industry and beyond which have relevance to the particular activity in the conceptual model step. In the following phase of the idea generation process, individual group members are required to brainstorm possible similar applications with relevance to their own situation. The group's ideas are then pooled. The process continues until all phases of the conceptual model have been considered.

Overall, a structure for supporting the generation of ideas is used to drive the identification exercise. The process is broken down into stages in which a finely focused component of a conceptual model (for example, the customer resource life cycle model), with supporting case studies, is used to examine one by one key aspects of the organization's business. For example, a GDSS that incorporates snow-card or NGT methods, can be used to assist and manage the information exchange between strategic thinkers as they systematically search for strategic customer transactions using, one at a time, each of the 13 phases of the customer resource life cycle model. This level of support is currently provided by present GDSS technology (see DeSanctis et al., 1987), and the technology can be extended to embed the details of a conceptual model and parallel case studies within the GDSS framework.

The integration of idea generation techniques, conceptual models and case studies can of course be done manually. However, it does seem eminently sensible of the information systems profession to use its own technology in its search for strategic information systems. The information intensive nature of the often long and multi-level link between producer and final user, provides many opportunities for IST to reshape systems to increase competitive performance. Organizations that are adept at processing and using information more rapidly and smartly than their competitors, or use IST to distribute products and services more efficiently, can gain an advantage in their industry. This paper has provided an appraoch for the integration of avenues available for searching for IST advantage: idea generation; case studies; and, conceptual models.

\section{Notes}

1. Personal communication by one of the authors with senior executives of a major South African record distributor who wish to remain anonymous at the time. November, 1988.

2. Personal communication by one of the authors with the sales manager of a major South African pharmaceuticals manufacturer who wishes to remain anonymous at the time. November, 1988.

3. Personal communication by one of the authors with senior executives of a major South African hardware wholesaler who wish to remain anonymous at the time. November, 1988.

\section{References}

Applegate, L.M. 1986. Idea generation in organizational planning. Unpublished Ph.D. Dissertation, University of Arizona.

Bandura, A. 1977. Social learning theory. Prentice Hall Inc., Englewood Cliffs, N.J.

Beath, C.M. \& Ives, B. 1986. Competitive information systems in support of pricing. MIS Quart., vol.10(1), 85-96.

Brancheau, J.C. \& Wetherbe, J.C. 1987. Key issues in information systems management. MIS Quart., vol.11(1), 23-45.

Business Week, December 7, 1981. Various references, pp. 115, 116, 118, 122.

Delbecq, A.L. \& Van de Ven, A.H., 1971. A group process model problem planning, identification, and program planning. J. Appl. Behaviour. Sci., vol.7(4), 466-492.

DeSanctis, G. \& Gallupe, R.B. 1987. A Foundation for the Study of group decision support systems. Manage. Sci., vol.33(5), 589-609.

DeSanctis, G., Sambamurthy, V. \& Watson, R.T. (In press). Computer-supported meetings: Building a research environment. Large Scale Systems.

Duke, R.D. \& Greenblatt, C.S. 1979. Games generating games: a trilogy of games for community and classroom. Sage, Beverley Hills, CA.

Gordon, W.J.J. 1961. Synectics Harper and Row, New York, NY.

Hirokawa, R.Y. \& Pace, R. 1983. A descriptive investigation of the possible communication-based reasons for effective and ineffective group decision making. Comm.

Monographs, vol.50, 363-379.

Information Week, May 26, 1986. Special issue:strategic systems.

Ives, B. \& Learmonth, G.P. 1984. The information system as competitive Weapon. Comm. $A C M$, vol.27(12), 1193-1201.

Ives, B. \& Vitale, M.R. 1988. After the Sale: Leveraging Maintenance with Information Technology. MIS Quart., vol.12, 7-21. 
Jablin, F.M. \& Siebold, D.R. 1978. Implications for problem solving groups of individual and group problem solving. South. Speech Comm. J., vol.43, 327-356.

Osborn, A.F. 1941. Applied imagination: principles and procedures of creative thinking. Scribner, New York, NY.

Parsons, G.L. 1983. Information technology: a new acompetitive weapon. Sloan Manage. Rev., Fall, 3-14.

Porter, M.E. \& Miller, V.E. 1985. How information gives you competitive advantage. Harv. Bus. Rev., vol.63(4), 149-161.

Rogers, E.M. 1983. Diffusion of Innovations. 3rd Edition, The Free Press, New York, NY.

Van de Ven, A.H. \& Delbecq, A.L. 1974. The effectiveness of nominal, Delphi, and interacting group decision making processes. Acad. Manage. J., vol.17, 605-621.

Watson, R.T. \& Pitt, L.F. (In press). Remarrying marketing and logistics with IST. Industr. Manage. Data Systems, January-February, 1989. 